\title{
Compulsory licenses as a defense in pharmaceutical and biotech patent litigation
}

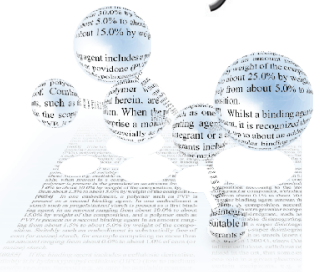

First draft submitted: 22 September 2016; Accepted for publication: 28 September 2016; Published online: 2 November 2016

Keywords: access to medicine $\bullet$ compulsory licenses $\bullet$ German Federal Patent Court - interim compulsory license $\bullet$ public healthcare $\bullet$ public interest

While compulsory licenses have previously largely been discussed in the context of generic companies trying to obtain rights to make and sell pharmaceutical products that are still protected by patents, more recently, compulsory licenses have also been used by innovator pharmaceutical companies as a defense tool against claims for injunctions against life-saving medicines. The present note discusses such a recent case from Germany and provides relevant background.

'Access to medicine' is a key concept at the interface of patents and pharmaceutical products. Pharmaceutical patents are a critical incentive for innovation and secure fundamental research by research institutions and commercial companies. At the same time adequate access to medicine for everybody is a fundamental goal in public healthcare.

The World Trade Organization has tried to take up this challenge and has, for the first time, in the context of the Agreement on Trade-Related Aspects of Intellectual Property Rights (TRIPS Agreement) established a set of rules dealing with intellectual property rights in a multilateral agreement. TRIPS came into force in 1995 and sets minimum standards for the protection of intellectual property rights which the member states have to implement in their legislation. Previously, the General Agreement on Tariffs and Trade had no specific rules on intellectual property rights [1] and most countries even excluded medicines from patent protection.
To clarify ambiguities between the needs of public healthcare and the guarantees contained in TRIPS to the owners of Intellectual Property rights, in November 2001 the declaration of the Fourth Ministerial Conference in Doha, Qatar (Doha Declaration) was added to support public healthcare by promoting access to existing medicines and the creation of new medicines [2]. Minimum standards for compulsory licenses and government use of a patent are now laid down in Article 31 of the TRIPS Agreement. Article 31 TRIPS generally requires that in order for a compulsory license to be granted if (a) the proposed user has made efforts to obtain authorization from the right holder on reasonable commercial terms and conditions and that (b) such efforts have not been successful within a reasonable period of time, (c) the license shall be purpose limited and (d) non-exclusive and (e) authorized predominantly for the supply of the domestic market of the Member authorizing such use, and finally, (f) the right holder shall be paid adequate remuneration in the circumstances of each case, taking into account the economic value of the authorization.

\section{Compulsory licenses in Germany}

Provisions dealing with compulsory licenses were already part of the German Patent Act before the TRIPS Agreement, but to comply with its provisions Germany amended its Patent Act in 1998 by virtue of the second

\author{
Andreas von Falck \\ Hogan Lovells International LLP, \\ Kennedydamm 24, 40476 Düsseldorf, \\ Germany \\ andreas.vonfalck@hoganlovells.com
}

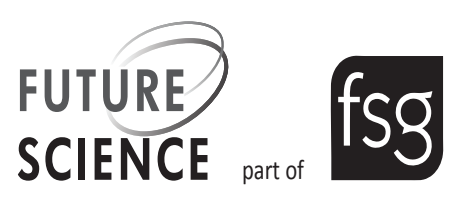


Amending Law for Patents [3]. Now, the requirements that have to be fulfilled so that a court may grant a compulsory license are laid down in section 24 of the German Patent Act. The potential licensee must have tried unsuccessfully to obtain a license from the patentee on reasonable and commercially acceptable terms and there must be a public interest in the grant of a compulsory license. Thus, compulsory licenses also reflect the social obligations of property rights thus limiting the guarantee of property rights set out in Article 14, section 2 of the German Constitution [4]. Compulsory licenses are not limited to the area of pharmaceutical products.

The term public interest is a legal concept that has to be interpreted by the courts and it may change over time. There is no precise definition of this legal term, but the interpretation of the courts depends on each individual case taken into account all relevant circumstances (recital 50 [5]). Thus, older decisions by the courts may not always be helpful for asserting new decisions as the needs of the public are constantly changing. However, the requirement of Article $31 \mathrm{sec}-$ tion (f) TRIPS that compulsory licenses are primarily for the supply of the domestic market of the Member authorizing such use gives an indication as to where the market can be supplied by means different from the product for which the compulsory license is sought.

Compulsory licenses must not be confused with 'exploitations orders' according to section 13 of the German Patent Act. Whereas a compulsory license is a non-exclusive license that a court grants a third party for using the invention and in return paying a royalty, orders of exploitations are orders by the government that restrict the effects of the patent in case an invention is needed for public welfare and security reasons, giving the patentee a right to seek compensation from the government (not from the user of the patented technology).

The competent court (the German Federal Patent Court [Bundespatentgericht] with a direct appeal to the German Federal Supreme Court [Bundesgerichtshof]) has to balance the necessary protection for the patentee including the patentee's decision not to grant licenses to third parties on the one hand, and the interest of the public in using the invention on the other hand. The mere fact that the patentee decides not to grant licenses to third parties does not suffice as a public interest in itself even if that leads to the patentee find himself in a monopoly position (recital 45 [6]). It is not sufficient for a compulsory license to be granted that the patentee 'misuses' his exclusive rights (recital 47 and $49[7]$ ), rather, there must be a compelling public interest. That means the needs of the public must be of such high importance that the exclusive position of the patentee has to step back. Only under those circumstances is the court interference with the monopoly granted to the patentee justified (recital $45[8]$ ). Therefore, compulsory licenses need to be handled in a very restricted manner.

In a recent case handled by the courts in Germany, the potential licensee/proposed user of the patent had made and sold a medicament in Germany since 2008 for use in the treatment of HIV infections. The patentee sued for patent infringement based on a patent granted in 2012 seeking an injunction. Given that German infringement courts do not have discretion in granting an injunction, the defendant in such a situation is caught in a dilemma. In case an injunction is granted, continuing the distribution would be fined by the court while at the same time the patient population urgently needs the continued supply with the medicament. At the time of the complaint, two medicaments with a similar mode of action had come on the market and the patentee argued that these medicaments were adequate alternatives to the product at issue and thus, that there was no public interest in the continuing distribution of the accused product. In response to the infringement action, the defendants filed a request for a compulsory license at the Federal Patent Court in Munich (Germany), and, as the hearing in the infringement matter moved closer, requested that the Patent Court issue an interim order under section 85 of the German Patent Act granting an interim compulsory license.

The court, after considering the evidence, concluded that the defendant was entitled to emergency relief and granted an interim compulsory license based on the need of patients to continue to have the accused product available in the course of ongoing treatment or as alternative or even emergency treatment. This was the first time in the history of the Federal Patent Court that an 'interim compulsory license' was granted [9].

In an earlier case, the courts decided that the public interest is not affected in cases where similar products may be used for the treatment of a disease (recital 50 [10]). But what does a 'similar' medicament mean? At first sight it might be easy to define what a similar medicament is: for instance, it should have similar effects and a similar side effect profile. But with more complex diseases such as HIV, individual treatment plans for every individual patient may require the continued availability of a certain product since every product switch can cause adverse reaction or reduce compliance. While one product may perfectly meet the needs of one patient or group of patients another similar product may cause different (and severe) side effects. Patients may develop resistance against a certain product and thus are dependent on another prod- 
uct available as substitute. Taking this into account, a similar, but not identical, product can make a huge difference for the individual patient and his medical needs during his treatment. This will always also have to be seen as a function of the seriousness of the disease.

On top of that, HIV as a highly infectious disease for which there is currently no cure, providing sufficient medical treatment for all kinds of HIV patients is also a way of controlling new infections and thus is a goal for public healthcare. Had it been a less infectious or fatal disease, the public interest might have been less affected and the courts would have decided differently.

In a similar case that started in 2010 [11] the patent court has equally found that the requirements of a compulsory license were present. The case concerned the continued supply with a product for a potentially life threatening orphan disease where the only competitor product was unavailable because of manufacturing issues. The case was, however, not finally decided by the court.

Access to medicine and compulsory licenses are two aspects of the law of intellectual property in the area of pharmaceuticals and biotech that belong together. The challenge is to find the right balance between the interests of the patentee and the public. In Germany, the courts in their recent decision showed that adequate access and continuous supply of medicine especially when it comes down to highly infectious and fatal diseases such as HIV is in the public interest and that in this case the exclusive position of a patentee has to step back for a greater good. It is equally clear, however, that this will not be a tool for generic manufacturers who argue that there is a public interest in cheap medicines and that a compulsory license should be granted in order to reduce costs for the healthcare system. Such an argument would be diametrically opposed to the function and purpose of the patent system, which is to encourage research and to reward successful search through a time limited monopoly. It would also destroy every incentive to invest into research for new and effective pharmaceutical products.

\section{Financial \& competing interests disclosure}

The author has no relevant affiliations or financial involvement with any organization or entity with a financial interest in or financial conflict with the subject matter or materials discussed in the manuscript. This includes employment, consultancies, honoraria, stock ownership or options, expert testimony, grants or patents received or pending, or royalties.

No writing assistance was utilized in the production of this manuscript.

\section{References}

1 Frequently asked questions about TRIPS (trade-related aspects of intellectual property rights) in the WTO (2016). www.wto.org/english/tratop_e/trips_e/tripfq_e.htm

2 The Doha Declaration explained (2001). www.wto.org/english/tratop_e/dda_e/dohaexplained_e.htm

3 Commentary Benkard/Rogge/Kober-Dehm, German Patent Act, 11th Edition 2015, section 24, recital 1.

4 Commentary Kraßer/Ann, Patent Law, 7th Edition 2016, section 34, recital 100.

5 German Federal Supreme Court, Karlsruhe (Bundesgerichtshof) X ZR 26/92 'Polyferon' (05.12.1995).

6 (Bundesgerichtshof) X ZR 26/92 'Polyferon'

7 German Federal Supreme Court, Karlsruhe (Bundesgerichtshof) X ZR 26/92 'Polyferon' (05.12.1995).

8 German Federal Supreme Court, Karlsruhe (Bundesgerichtshof) X ZR 26/92 'Polyferon' (05.12.1995).

9 German Federal Patent Court, Munich (Bundespatentgericht) 3 LiQ 1/16 (05.09.2016).

10 German Federal Supreme Court, Karlsruhe (Bundesgerichtshof) X ZR 26/92 'Polyferon' (05.12.1995).

11 German Federal Patent Court, Munich (Bundespatentgericht) 3 Li 1/10 (EP) (04.07.2012). 